\title{
Benefits of intradialytic physiotherapy in quality of life, pain, edema and respiratory function of patients with chronic kidney disease
}

Benefícios da fisioterapia intradialítica na qualidade de vida, dor, edema e função respiratória de doentes renais crônicos

Beneficios de la fisioterapia intradialítica en la calidad de la vida, el dolor, el edema y la función respiratoria de los pacientes renales crónicos

Hugo Machado Sanchez ${ }^{[a]}$, Denise Mendes Batista do Nascimento ${ }^{[a]}$, Kassia de Castro $^{[a]}$, Eliane Gouveia de Morais Sanchez ${ }^{[b]}$, Jair Pereira de Melo Junior ${ }^{[a]}$, Patrícia Leão da Silva Agostinho ${ }^{[]^{*}}$

[a] Universidade de Rio Verde (UniRV), Rio Verde, GO, Brazil

[b] Universidade Federal de Goiás (UFG), Jataí, GO, Brazil

\section{Abstract}

Introduction: Patients with chronic kidney disease suffer from a decline in quality of life and respiratory function, for various reasons related to this condition. Objective: To verify the influence of intradialytic physiotherapy on the quality of life and respiratory function in chronic renal patients. Methods: The sample was non-probabilistic and consisted of 51 individuals, of both

*HMS: PhD, e-mail: hmsfisio@yahoo.com.br DMBN: BS, e-mail: denisemb@hotmail.com KC: BS, e-mail: kassiacastrocpa@gmail.com EGMS: PhD, e-mail: egmfisio@yahoo.com.br JPMJ: PhD, e-mail: jnfjjunior@gmail.com PLSA: PhD, e-mail: p.leao@hotmail.com 
sexes, aged between 30 and 60 years. The WHOQOL-Bref, an evaluation form, the Manovacuometer and Peak Flow were used to detect the impact of the physiotherapeutic intervention before and after an eight-week treatment protocol. Results: There was a difference in the comparison of the general QOL before and after $(\mathrm{p}=0.006)$ the intervention, as well as in the improvement of the maximal forced expiratory flow peak $(p=0.001)$, the PEmax $(p=0.000)$, peak forced expiratory flow rate $(0.017)$ and pain $(p=0.006)$. There was also improvement of edema $(p=0.013)$ and cramps $(p=0.000)$. Conclusion: The benefits of intradialytic physiotherapy in improving QOL and respiratory function in chronic kidney patients are explicit.

Keywords: Chronic Renal Failure. Hemodialysis. Quality of Life. Physiotherapy. Respiratory Function Tests.

\section{Resumo}

Introdução: Pacientes com doença renal crônica sofrem declínio na qualidade de vida $e$ função respiratória, por diversos motivos ligados à afecção. Objetivo: Verificar a influência da fisioterapia intradialítica sobre a qualidade de vida e a função respiratória em pacientes renais crônicos. Métodos: A amostra foi não probabilística e composta por 51 indivíduos, de ambos os sexos, com idade estabelecida entre 30 e 60 anos. Utilizaram-se o WHOQOL-Bref, uma ficha de avaliação, o Manovacuômetro e o Pico de fluxo expiratório forçado máximo (Peak Flow) para detectar o impacto da intervenção fisioterapêutica antes e após um protocolo de oito semanas de tratamento. Resultados: Houve diferença na comparação da QV geral antes e depois $(p=0,006)$ da intervenção, assim como na melhora da PImáx $(p=0,001)$, da PEmáx $(p=0,000)$, do pico de fluxo expiratório forçado máximo $(p=0,017)$ e da EVA de dor $(p=0,006)$. Também houve melhora do edema $(p=0,013)$ e das câimbras $(p=0,000)$. Conclusão: Ficam explícitos os benefícios da fisioterapia intradialítica na melhora da QV e a função respiratória de doentes renais crônicos.

Palavras-chave: Insuficiência Renal Crônica. Hemodiálise. Qualidade de Vida. Fisioterapia.

Testes de Função Pulmonar.

\section{Resumen}

Introducción: Los pacientes con enfermedad renal crónica sufren una disminución de la calidad de vida y la función respiratoria, por diversos motivos relacionados con la afección. Objetivo: Verificar la influencia de la Fisioterapia intradialítica sobre la calidad de vida, función respiratoria en pacientes renales crónicos. Métodos: La muestra fue no probabilística y compuesta por 51 individuos, de ambos sexos, con edad establecida entre 30 a 60 años. Se utilizó el WHOQOL-Bref, una ficha de evaluación, el Manovacuómetro y el Pico de flujo espiratorio forzado máximo (Peak Flow) para detectar el impacto de la intervención fisioterapéutica antes y después de un protocolo de ocho semanas de tratamiento. $(P=0,006)$ de la intervención, así como en la mejora de la PImáx $(p=0,001)$, de la PEmáx $(p=0,000)$, del pico de flujo espiratorio forzado máximo $(p=0,000)$, en la comparación de la QV general antes y después $(p=0,006)$ $0,017)$ y de la EVA de dolor $(p=0,006)$. También hubo una mejora del edema $(p=0,013)$ y de los calambres $(p=0,000)$. Conclusión: Queda explícito los beneficios de la fisioterapia intradialítica en la mejora de la QV y la función respiratoria de pacientes renales crónicos.

Palabras clave: Insuficiencia Renal Crónica. La hemodiálisis. Calidad de vida. Fisioterapia. Pruebas de Función Pulmonar. 


\section{Introduction}

The kidneys are organs that execute various functions such as filtration, absorption, endocrinologic and metabolic homeostasis. The kidneys' role is to maintain the homeostasis which regulates the internal environment through reabsorption of substances and filtered ions inside the glomeruli and other substances excretion [1].

Chronic Renal Failure (CRF) is understood as a kidney lesion where it will occur an irreversible and progressive loss of the renal function which becomes a homeostatic imbalance in the body [1-3].

The Chronic Kidney Disease (CKD) is related to protein-energy malnutrition that can be caused by deficient intake of essential nutrients for the body, and that can make the patient's prognosis and their quality of life (QOL) worse [2].

The systemic arterial hypertension (SAH) and the renal disease, when not controlled correctly, can start a vicious circle that consists in the increase of the blood pressure, causing a primary renal lesion or the renal disease progression at the terminal stage [3].

Some people during the hemodialysis treatment phase present a decrease in their physical conditioning and become unable to fulfill any physical activity. The sedentary lifestyle gets even worse with comorbidities such as: anemia, cardiopathy, blood pressure, neuropathy and myopathy [4].

The sedentary lifestyle and the conditioning decrease are also due to the fact that the respiratory system may be affected by both the disease and the hemodialysis treatment. Patients with CKD undergoing hemodialysis show lung function and respiratory muscle strength decrease [5].

The muscular strength of CKD patients is decreased and therefore there may be a large decrease in the maximal inspiratory pressure (IPmax) and the maximal expiratory pressure (EPmax). In normal people, the IPmax can have a medium value of about $115+/-25$ $\mathrm{cmH}_{2} \mathrm{O}$ and EPmax with a normal value in a young adult is about +100 to $+150 \mathrm{cmH}_{2} \mathrm{O}$ [6].

The CRF and the hemodialysis treatment compromise not just the physical but also the physiologic aspects, with personal, familiar and social repercussions for the patient, which makes it necessary to relearn how to live [7]. Patients in dialysis have difficulties in keeping themselves employed and finding professional occupations, for the IRC decreases the physical capacity and the hemodialysis sessions increase the absence rate at work, resulting in the reduction of the monthly family income. It also promotes the decrease in sexual interest, the fear of death and changes in body image, and social support becomes necessary as part of the hemodialysis treatment [8].

The QOL is an important criterion in the treatment evaluation and in health field interventions. This parameter has been used to investigate the impact of the chronic diseases in the people's daily life [9].

Considering that, physiotherapy can bring benefits to the QOL of these patients; as the patients in Intensive Therapy Units (ITU) need daily physiotherapy, the hemodialysis patients also need this kind of work, because of the pulmonary improvement complacency which will increase the muscle strength, with consequently decrease of dyspnea, improvement of the articular mobility, decrease of hypertrophy, improvement in the functional capacity, and in the daily and labor activities of these patients [10].

The intradialytic physiotherapy can improve many aspects such as the patient's satisfaction, sexual function and general health [2]. It can also reduce the cardiac frequency/respiratory frequency along with the systolic blood pressure stabilization (BPS). It can improve muscle strength, increase the tolerance at exercises, reduce the level of pain, improve the performance in Daily Activities (DA) (e.g. go up and down the stairs; there's improvement in the ambulation capacity and, at the same time, in the capacity of completing exercises or other tasks that require physical resistance), providing cardiovascular and respiratory conditioning (increase in the capacity of gas changes and strengthening of the respiratory muscles) [4]. This way, the patients can present improvement in the autonomy, personal independence and better social reintegration, all factors that make up domains of the QOL according to the World Health Organization (WHO) [10].

The present work had as general objective to verify the influence of the intradialytic physiotherapy in the life quality and respiratory functions in renal chronic patients.

\section{Methods}

It is a non-randomized clinical test, at a private clinic located in the countryside of the state of Goias. This is an intervention research, called before and after, in which the individual acts as his own control. The whole population receives the same intervention and their condition is verified before the beginning and again after it. Thus, there is no necessity of establishing a parallel group [11]. The research was done after the appreciation by the Research Ethnical Committee (REC) respecting 
the research ethical precepts involving human beings, and approved as number 1.220.959.

The sample was non-probabilistic and composed by 51 individuals, both genders, with the established age between 30 to 60 years old. It came to this sample number after the application of the exclusion criteria and invitations to every patient of the clinic, totalizing 74 patients. However, the sample was defined only after the patients' acceptance.

It was included in the study the individuals of both genders between 30 to 60 years old, with CRD diagnosed by a nephrologist doctor and Diabetes Mellitus (DM) and SBP as base diseases. It is important to refer that the inclusion of the patients in the study just occurred after the nephrologist doctor responsible for the clinic had released the patients to take part in the physiotherapeutic protocol, therefore they presented normal laboratory results (no anemia, this means, 32 to $37 \mathrm{~g} / \mathrm{dL}$ hemoglobin, glycaemia till $125 \mathrm{mg} / \mathrm{dL}$, platelets of 140.000 to $400.000 / \mathrm{mm}^{3}$ and PTH between $10-60$ $\mathrm{pg} / \mathrm{mL}$ ) and good clinical conditions.

Individuals that fitted any of the following characteristics were excluded: non-controlled hemodynamic instability; fistula in the lower limbs (MMII); cognitive deficit or incoordination to execute the equipment used; non-controlled DM and HAS; those who present respiratory disease (chronic obstructive pulmonary disease, asthma), congestive heart failure class $\mathrm{C}$ and $\mathrm{D}$ according to the criteria of the American College of Cardiology/American Heart Association, physical impairment that disabled the study (amputation, deep vein thrombosis, active gastrointestinal bleeding); those who gave up treatment, who had changes in the complementary tests, those in poor general health condition and the incomplete answered questionnaires.

The data collected was achieved using four instruments. The first instrument is an evaluation sheet that was made by the authors themselves, which contained sociodemographic data, data related to the exclusion criteria and gaps to be filled with the following information: time they have been undergoing hemodialysis, lung function, blood pressure (daily), presence of edema, presence of cramps, presence of orthostatic hypotension, data concerning the exclusion criteria, analogic visual scale (AVS) of pain. The pain, edema and cramps assessment was addressed before and after the intervention. For the evaluation of the pain by the AVS, the patient was asked to mark a point in a linear line of $10 \mathrm{~cm}$, not numbered and indicating in one of the endpoints the "absence of pain", and in the other end, the "worst pain imaginable". For the evaluation of the edema, the physical exam (inspection and palpation) was done. This kind of evaluation doesn't establish just a diagnostic instrument, but also a risk identifier for associated complications [12].

The second instrument evaluates the respiratory muscle strength by the maximal inspiratory and expiratory pressures (IPmax: $115+/-25 \mathrm{~cm} \mathrm{H}_{2} \mathrm{O}$ and EPmax: +100 to $+150 \mathrm{~cm} \mathrm{H}_{2} \mathrm{O}$ ), starting with the residual volume and from the total lung capacity, respectively, making use of the manuvacuometer connected to a nozzle, which measures pressures from 0 to $120 \mathrm{~cm}$ $\mathrm{H}_{2} \mathrm{O}$ for inspiratory and expiratory pressures [13].

The third instrument evaluates the peak expiratory flow forced to maximum (PEF) through the Peak Flow appliance (Assess), developed by Respironics New Jersey, Inc., 41 Canfield Road. The appliance registers the $\mathrm{PEF}$ in $\mathrm{L} / \mathrm{min}$, being possible a lower value $=60$ $\mathrm{L} / \mathrm{min}$ and a higher value $=850 \mathrm{~L} / \mathrm{min}$. It allows the researchers to evaluate the severity of bronchial obstruction. The appliance is connected to a nozzle and the volunteer is instructed to make a forced and quick expiration from his/her total lungs capacity. For the evaluations above a clip that occludes the nasal orifice was used and measures were done, with the register of the highest one [14].

The fourth instrument was the quiz proposed by the World Health Organization (WHO) for the life quality evaluation, called WHOQOL-bref (World Health of Quality of Life-Bref). It is a global instrument created by WHO to evaluate the QOL. It can be used to evaluate the QOL of any disease and/or population. Also, it is multidimensional, because in its making they sought to cover the different aspects related to health and well-being; for this reason, it is composed of 24 facets. Besides, it is the most used instrument to evaluate the QOL in generic or specific form, being also the most used for evaluation of QOL in CRD. Since it has a transcultural character, it can be used in any place, allowing the development of collaborative research in several centers, with different cultures, and their comparison, which helps the health studies by providing evidences on the systematic monitoring in multinational clinics. This information is necessary to investigate those interventions that are not routinely assessed, such as the case of the physiotherapeutic intervention in CRD [15]. 
The instrument has 26 questions, being 2 questions about QOL. The other 24 are divided in four domains: Physical (pain and discomfort; energy and fatigue; sleep and resting; mobility; activities from daily life; medication or treatments dependence; work capacity); psychological (positive feelings; thinking, learning, memorizing and concentration; self-esteem; body image and appearance; negative feelings; spirituality/religion/ personal believes); social relations (personal relations; social support; sexual activity); and environment (physical security and protection; environment at home; financial resources; health and social care: availability and quality; opportunities to acquire new information and abilities; participation in and opportunities of recreation/leisure; physical environment: pollution, noise, traffic, climate; transportation) [16]. The results achieved with the validation process of the WHOQOLbref in the Portuguese version in Brazil and at the others research centers obtained a good performance with satisfactory characteristics, discriminant validity and reliability, performed in the same form of the process initiated with the WHOQOL-100 validation.

In this study all questionnaires were selfadministered. However, in case of doubt, the researchers were available to support the respondents, becoming this way an assisted application. First, a presentation about the research was done to the volunteers, so that they could be aware of what was happening.

The volunteers were individually lead into a room available inside the clinic. A brief description about the research was shown to the patients, pointing out its objectives and its relevance to chronic renal patients.

In case of acceptance, the volunteers signed down the TCLE twice (one copy was kept with the individual and the other with the researchers). Then, a physiotherapeutic evaluation was done during the hemodialysis. This evaluation was standardized and done by the researchers themselves through an interview using an Individual Evaluation Form. After the volunteer's evaluation, a questionnaire was given to him/her: WHOQOL-bref. The volunteer could choose to answer it immediately or to take it home and subsequently bring it back.

After these steps, the intradialytic physiotherapeutic treatment was introduced during the first hours of the sessions, respecting the participant's clinical condition, each session lasting 25 minutes, three times per week, for eight weeks, totalizing 24 sessions.
In the first moment, the hemodynamic was evaluated by picking up the data regarding the general state of the patient. The volunteer was dismissed from physiotherapy when they presented a significant pain chart, dizziness, accentuated hypertension and hypotension. The member that had the venous access was not mobilized to avoid the impairment risk. In each day of intervention self-stretching and/or passive stretching, strengthening exercises, circulatory exercises and respiratory exercises were done.

The exercises were done in supine and sedestation position, in a tilting armchair. In the beginning of the physiotherapeutic care visits, stretching exercises were done for 15 seconds with the following muscle groups: flexor and/or wrist extensor, quadriceps, hamstrings, triceps sural, adductors and/or hip abductors, paravertebral and spinal region.

Circulatory exercises were done in three series with five repetitions for each exercise of: triceps sural strengthening, wrist and/or shoulder circumference, fingers bending and/or extension. Resistive kinesiotherapy using $1 \mathrm{~kg}$ halter and shin guard for three series with five repetitions consisted of: extended leg lift, knees bending and/or extension, hips abduction and/ or adduction, hips with legs extended circumference, triple flexion of MMII, shoulder and elbow bending and/ or extension and shoulder abduction and/or adduction.

The respiratory exercises were done in five repetitions using re-expansive ventilatory standards: fractional expiration and inspiration, inspirational sobs, maximum inspiration support associated with the pursed-lip. At the end of the section, the hymodinamic of the volunteer was reevaluated. At the end of the study, the physiotherapeutic evaluation form and the WHOQOL-bref were reapplied, with the purpose of comparing the data collected during the research time.

It is important to point out that all the evaluation and tests were applied by evaluators trained and able to execute such tasks, as well as to implement the intervention plan.

A descriptive statistical analysis in Excel $2013^{\circledR}$ was done for data analysis, followed by Student's t-test for the comparison of the numerical results before and again after the intervention, qui-squared test for comparison of the nominal results before and after the intervention and Pearson's correlation coefficients to correlate age with the QOL score.

The SPSS $20.0^{\circledR}$ program was used for such analyses considering significant values of $\mathrm{p}<0.05$. 


\section{Results}

The sample was composed of 51 patients being 13 women and 38 men with CRF, in average aged 53.78 \pm 10.89 years old, with a hemodialysis time of $4.5 \pm$ 3.6 years, with the weekly frequency of 3 hemodialysis sessions per week ( 4 hours of duration each). The data presented on Figure 1 shows the comparisons of the general QOL and the dominium of the QOL before and after the intervention.

It was seen an statistical difference $(p=0.006)$ in the general QOLbefore $(12.75 \pm 2.46)$ and after the intervention (14.30 \pm 2.52$)$, as well as in the physical dominium, which obtained significant difference $(\mathrm{p}=0.004)$ before $(11.99$ $\pm 3.30)$ and after $(13.75 \pm 2.81)$, in the psychological dominium ( $p=0.028$; before $13.93 \pm 2.84$ and after 15.24 \pm 3.07 ) and in the environmental dominium ( $p=0.002$; before $11.91 \pm 2.75$ and after $13.81 \pm 2.75$ ) .

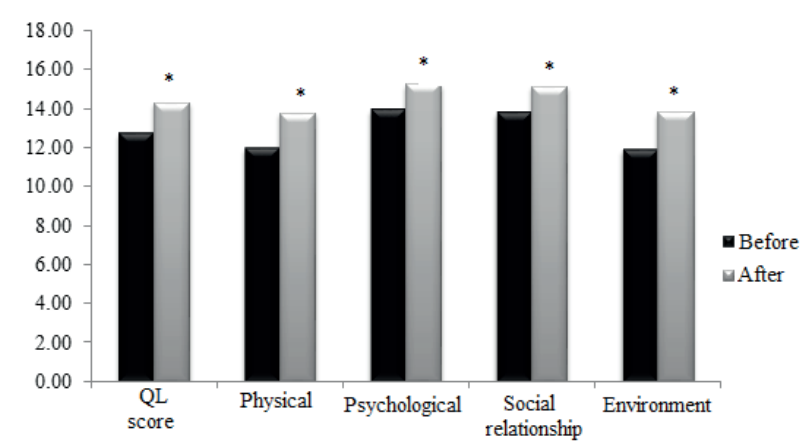

Figure 1 - Comparison of the QOL and its dominium before and after the intervention $(n=51)$. Student's t-test.

The data presented in Table 1 shows the comparison of the IPmax, EPmax and the peak expiratory flow before and after the intervention. As it was presented in this table, it was observed a statistical difference in the IPmax ( $\mathrm{p}=0.001)$ before $\left(50.10 \pm 26.18 \mathrm{cmH}_{2} \mathrm{O}\right)$ and after $\left(62.90 \pm 28.30 \mathrm{cmH}_{2} \mathrm{O}\right)$ the intervention, as well as in the EPmax ( $p=0.000$; before: $43.40 \pm 24.90$ $\mathrm{cmH}_{2} \mathrm{O}$; after: $62.80 \pm 26.05 \mathrm{cmH}_{2} \mathrm{O}$ ) and in the peak expiratory flow forced at maximum $(\mathrm{p}=0.017$; before: $420.00 \pm 155.38 \mathrm{~L} / \mathrm{min}$; after: $626.20 \pm 871.12 \mathrm{~L} / \mathrm{min}$ ) of the intervention.

Table 1 - Comparison of the IPmax, EPmax and peak expiratory flow before and after the intervention $(n=51)$

\begin{tabular}{cccc}
\hline Variables & Before & After & p value \\
\hline $\mathrm{IP} \max \left(\mathrm{CmH}_{2} \mathrm{O}\right)$ & $50.10 \pm$ & $62.90 \pm$ & 0.001 \\
& 26.18 & 28.30 &
\end{tabular}

\begin{tabular}{cccc} 
Variables & Before & After & p value \\
\hline EPmax $\left(\mathrm{cmH}_{2} \mathrm{O}\right)$ & $43.40 \pm$ & $62.80 \pm$ & 0.000 \\
& 24.90 & 26.05 & \\
Peak expiratory flow & $420.00 \pm$ & $626.20 \pm$ & 0.017 \\
$(\mathrm{~L} / \mathrm{min})$ & 155.38 & 871.12 & \\
\hline
\end{tabular}

In the comparison of the analogic visual scale (AVS) of pain it was also verified significant differences $(\mathrm{p}=$ $0.006)$ before $(3.19 \pm 3.16)$ and after $(1.62 \pm 2.86)$ the intervention. The data presented in Figure 2 show the comparison of edema, cramps and orthostatic hypotension before and after the intervention.

It was observed a statistical difference in the edema ( $p=0.013)$ before $(26 \pm 13)$ and after $(24 \pm 37)$ intervention, as in the patient's number of cramps ( $p$ $=0.000 ; 36 \pm 16$ before and $14 \pm 34$ after). Regarding the orthostatic hypotension there was no statistical difference $(p=0.317)$ between before $(29 \pm 23)$ and after $(21 \pm 27)$ the intervention.

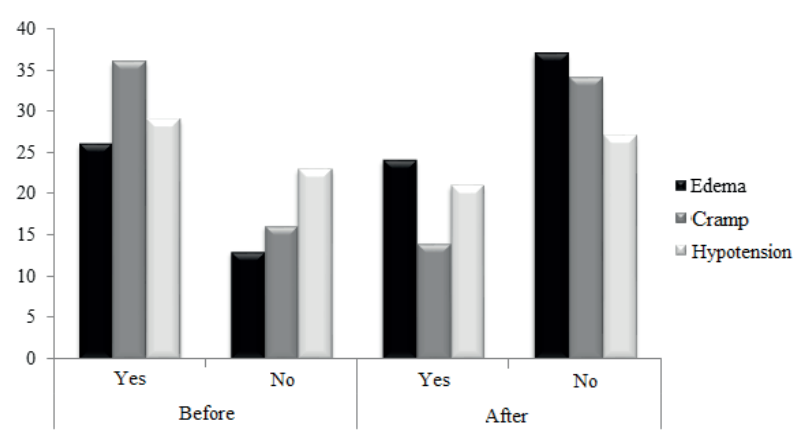

Figure 2 - The treatment influence in the edema, cramps and hypotension before and after the intervention $(n=51)$. Student's t-test.

There was no significant correlation between age and QOL for patients of kidney disease either before $(\mathrm{r}=0.41$ $\mathrm{e} p=0.534)$ or after $(\mathrm{r}=0.132 \mathrm{e} \mathrm{p}=0.421)$ intervention.

\section{Discussion}

The results obtained in the present study show that patients with CRF present an improvement in their general QOL with a Physiotherapy program during their hemodialysis, a fact that suggests the Physiotherapy program insertion in their daily life for good and constant changes in their quality of life. A physiotherapy program during the hemodialysis could allow them to have a significant improvement in the quality of life and physical capacity of the chronic kidney patients, as it was discussed in this study. 
The practice of the exercises, in general population and in the population of patients with chronic diseases, is related to the improvement of the cardiovascular parameter, quality of life and in the increase in the survival.

One of the uses of the exercises practice in general population and in the population of patients with chronic diseases is related to the improvement of the cardiovascular parameters, increase of the quality of life and survival. Lara et al. [17] showed that the physiotherapy, when done during the hemodialysis, offered an improvement in the quality of life and in the four dominium. It was observed a relevant clinical improvement in this study in the physical, psychological, social relation and environmental aspects of the participants, as well as in the study of Fassbinder et al. [18].

The physiotherapeutic treatment has impact in the various dominium of the quality of life: in the physical dominium (the one that deals with issues related to pain, mobility and daily activities), in the physiologic dominium (self-esteem, negative/positive feelings), in the dominium of the social relations (social support and relations) and in the environmental dominium (home environment, health care, opportunities to acquire new information and leisure). Most likely, when the individual is able to complete their daily activities with little effort and pain, they feel less tired and more motivated, which indicates less energy expenditure in the Das and more functional independence, more willingness, grater interaction, increase of the capacity to fulfill everyday tasks and labor and improvement in interpersonal relationships such as familiar as well as extra-familiar, because, according Veena [19], all these dominium are visibly impaired in these patients.

In the point of view of Silva et al. [20], the CRD patient lives with a disease that forces them to submit themselves to a painful treatment, with long hours that cause many limitations and complications that come from the dialytic therapy and from the renal disease itself, among them the decrease of the physical activities and functional capacity, predisposing them to physical alterations such as: muscular atrophy, weakness, tiredness and pain all over the body, making it harder to fulfill the daily activities and impairing their QOL.

After the physiotherapeutic intervention, it was detected in the study a decrease in the pain level of the participants of the research, an improvement that can be explained by the muscle strengthening, which causes decompression and decreases in the joint shear, as well as the improvement in the myotendinous and joint circulation, which along muscle strengthening generates joint stability and increasing of the flow in these structures, which confirms the studies of Böhm et al. [21].

The relevance of the physiotherapeutic intervention in the pain is also referred in the studies of Soliman et al. [22] and Lima et al. [23], in which the patients with CRF complain frequently about discomfort and pain, mainly in the lumbar and cervical region, that can be explained by many reasons, such as: presence of musculoskeletal disorder, remaining in seated and static position, and standard chairs which do not respect the ergonomic individualities of each patient.

This way, the improvement of the QOL verified in the present study enables to the CRD lower levels of pain, improvement in the rest and sleep patterns. These improvements can lead to the decrease in the use of pain medicines, fatigue and sleepiness. Added to this there are other factors: more willingness to fulfill the daily activities/professional activities, improvement of the selfesteem/corporal image, followed up by an improvement in the sexual life and more socialization. Besides, it allows for greater concentration, more control and movement dominium, which allows home safety inside and out of it, as well as willingness to seek a new job/occupation, to integrate oneself and have more experiences with recreation/leisure. From the moment the patient with CRD is feeling secure and able to execute new functions in society and at work he/she will seek a job opportunity and because of that, achieve more financial resource, which can enable better health conditions, transportation, leisure, education, and security, among others.

In the current research, it was observed significant improvement in relation to the cramps after the physiotherapeutic performance since stretching returns to the muscle its length and normal elasticity. The Strengthening exercises improve the muscle regular tension, assisting the venous return, attenuating the rapid loss of liquid that hemodialysis causes, besides promoting the muscle strength necessary to the daily activities accomplishment. Minetto et al. [24] observed that the muscle stretching causes an abrupt interruption of cramps and increases the threshold, for its triggering (activation of the Golgi tendon organ), associated to points of trigger. The treatment through muscle stretching exercises is simple and effective, and it decreases and prevents the frequency and intensity of cramps according to Reboredo et al. [25]. 
In relation to the hypotension there was no statistical difference in the present study. According to Soares et al. [26] there are two types of arterial hypotension: the first one occurs typically at the end of the treatment and the other one, that is a chronic and persistent form, happens in a group of patients that has systolic blood pressure, pre-dialysis lower than 90-100 $\mathrm{mmHg}$ and whose frequency decreases more during the dialysis. One of the causes of the hypotension is related to cardiac factors, by a cardiac deficit excessively dependent of a diastolic dysfunction, an incompetence in increasing the cardiac frequency, whether by use of beta blockers, by uremic neuropathy, aging, among others.

Bradshaw's [27] discoveries show that the arterial hypotension is, without doubts, the main complication of the hemodialysis treatment, and it occurs in between 15 to $55 \%$ of the patients in treatment. The physiopathology involves the ultrafiltration rate, decreased osmolarity, the temperature of the dialysate, reduction of intravascular volume, hyponatremia, increased release of vasodilatory substances and reduced release in the vasoconstrictors, leading to a reduction of the cardiac output and the peripheral vascular resistance. Due to the etiological complexity of the hypotension in the CRD the physiotherapeutic intervention would need more time for the results to be observed.

About the edema in particular, the results of this study show that there were significant differences between the participants, in which the individuals that underwent the physiotherapeutic treatment presented reduction in the presence of edemas. [28]

Studies pointed out that the muscle pump mechanism in lower limbs facilitates the venous return for it promotes an increase of pressure on the deep venous system by the contraction of the local muscles. For these reasons, the physiotherapeutic approach values the procedures of the kinesiotherapy and stretching of the shortened muscle chains.

In the current research, a significant improvement was observed in relation to the IPmax, EPmax and PEF, after the physiotherapy performance. This study confirms the one made by Faria et al. [29] showing a significant increase in the respiratory musclestrength, both immunosuppressive and expiratory, which were evaluated by means of manovacuometry, presenting a significant improvement after the hemodialysis sessions. The respiratory system function is unregulated in the CKD, which causes imbalance in gas exchanges. It can be said that this alteration is also a factor that reduces the patient's capacity of practicing physical exercises, because during the activities, it is of great importance the integrity of the ventilation capacity and the use of oxygen, both aspects that are reduced in CKD patients, and provide a decrease in respiratory muscle strength [30,31].

In the Rocha et al. study [32], it was observed the significant improvement of the PEF, EPmax and IPmax after the physiotherapy performance, justified by the balance between the removal of fluids during the dialysis and the bronchoconstriction due to the biocompatibility of dialysis membrane and by the lung expansion capacity through simple and effective techniques of diaphragmatic breathing.

Despite the positive and relevant results presented by this study, few hemodialysis services rely on professional physiotherapists in their CKD care team, so this study follows the new trends and warns about the underestimation of the introduction of this professional both in hemodialysis clinics and in nephrology services for patients who have diseases such as SAH and MD. However, other tools of greater accuracy and that allow more detailed functional evaluation could be used, such as spirometry, the power platform, the dynamometry and volumetry, in order to make possible the purchase of the efficacy of intradialytic physiotherapy with even more robust scientific data. In addition, other physiotherapeutic techniques could have their efficacy for the treatment of this group of patients proven, with the purpose of increasing the possibility and variety of procedures that professionals could use.

\section{Conclusion}

The physiotherapeutic rehabilitation program, when performed during hemodialysis is beneficial for the improvement of the QOL of chronic renal patients in all their facets (physical, social, environmental and psychological). The regular physiotherapy intervention is also associated to a lower frequency of edema and cramps and to the decrease of the pain. It also influences the improvement of the respiratory function, showed by the evolution of the values of the IPmax, EPmax and peak expiratory flow.

\section{References}

1. Baumgarten M, Gehr T. Chronic Kidney Disease: Detection and Evaluation. Am Fam Physician. 2011;84(10):1138-48. 
2. Padulla SAT, Matta MV, Melatto T, Miranda RCV, Camargo MR. A fisioterapia pode influenciar na qualidade de vida de indivíduos em hemodiálise? Cienc Cuid Saude. 2011; 10(3):564-70.

3. Segura, J, Ruilope, LM. Hypertension in moderate-tosevere nondiabetic CKD patients. Adv Chronic Kidney Dis. 2011;18(1):23-7.

4. Girija K, Radha R. Beneficial effect of physical activity in hemodialysis patients. Univ J Eng Sci. 2013;1(2):40-4.

5. Teixeira CG, Duarte MCMB, Prado CM, Albuquerque EC, Andrade LB. Impact of chronic kidney disease on quality of life, lung function, and functional capacity. J Pediatr (Rio J). 2014;90(6):580-6.

6. Palamidas AF, Gennimata SA, Karakontaki F, Kaltsakas G, Papantoniou I, Koutsoukou A, et al. Impact of hemodialysis on dyspnea and lung function in end stage kidney disease patients. Biomed Res Int. 2014;2014:212751.

7. Niemczyk S, Niemczyk L, Romejko-Ciepielewska K. Basic endocrinological disorders in chronic renal failure. Endokrinol Pol. 2012;63(3):250-7.

8. Cruz MC, Andrade C, Urrutia M, Draibe S, Martins LAN, Sesso RCC. Quality of life in patients with chronic kidney disease. Clinics (Sao Paulo). 2011;66(6):991-5.

9. Weldam, SW, Schuurmans, MJ, Liu, R, Lammers, JW. Evaluation of Quality of Life instruments for use in COPD care and research: a systematic review. Int J Nurs Stud. 2013;50(5):688-707.

10. Silva SF, Pereira AA, Silva WAH, Simôes R, Barros Neto JR. Fisioterapia durante a hemodiálise de pacientes com doença renal crônica. J Bras Nefrol. 2013;35(3):170-6.

11. Hochman B, Nahas FX, Oliveira Filho RS, Ferreira LM. Desenhos de pesquisa. Acta Cir. Bras. 2005;20(Suppl2):2-9.

12. Maicá AO, Schweigert ID. Avaliação nutricional em pacientes graves. Rev Bras Ter Intensiva. 2008;20(3):286-95.

13. Bianchi PDA, Barreto SSM, Thomé FS, Klein AB. Repercussão da Hemodiálise na Função Pulmonar d e Pacientes com Doença Renal Crônica Terminal. J Bras Nefrol. 2009;31(1):25-31.

14. Pezzini CA, Zanata J, Maraschin R, Mortari DM, Scapini K, Leguisamo CP. Repercussão da hemodiálise na função pulmonar e força muscular ventilatória em pacientes com doença renal crônicaterminal. Fisioter Bras.2012;13(2):112-7.
15. Kluthcovsky ACGC, Kluthcovsky FA. O WHOQOL-bref, um instrumento para avaliar qualidade de vida: uma revisão sistemática. Rev Psiquiatr Rio Gd Sul. 2009; 31(3):286-95.

16. Bredemeier J, Wagner GP, Agranonik M, Perez TS, Fleck MP. The World Health Organization Quality of Life instrument for people with intellectual and physical disabilities (WHOQOL-Dis): evidence of validity of the Brazilian version. BMC Public Health. 2014;14:538.

17. Lara CR, Santos FAOG, Silva TJ, Camelier FWR. Qualidade de vida de pacientes renais crônicos submetidos à fisioterapia na hemodiálise. Cienc Saude Colet. 2013;6(3):163-71.

18. Fassbinder TRC, Winkelmann ER, Schneider J, Wendland J, Oliveira OB. Functional Capacity and Quality of Life in Patients with Chronic Kidney Disease In Pre-Dialytic Treatment and on Hemodialysis - A Cross sectional study. J Bras Nefrol. 2015;37(1):47-54

19. Veena, DJ. Quality of life in end stage renal disease patients. World J Nephrol. 2014; 3(4):308-16.

20. Silva SF, Pereira AA, Silva WAH, Simôes R, Barros Neto JR. Fisioterapia durante a hemodiálise de pacientes com doença renal crônica. J Bras Nefrol. 2013;35(3):170-6.

21. Böhm J, Monteiro MB, Thomé FS. Effects of aerobic exercise during haemodialysis in patients with chronic renal disease: literature review. J Bras Nefrol. 2012;34(2):189-94.

22. Soliman, RA, Fawzy, M, Kandil, H, Fattah, AA. Assessment of hypotension during dialysis as a manifestation of myocardial ischemia in patients with chronic renal failure. The Egyptian Journal of Critical Care Medicine. 2014;2(1):13-8.

23. Lima FF, Miranda RCV, Silva RCR, Monteiro HL, Yen LS, Fahur BS, et al. Avaliação funcional pré e pós-programa de exercício físico de pacientes em hemodiálise. Medicina (Ribeirao Preto). 2013;46(1):24-35.

24. Minetto MA, Holobar A, Botter A, Farina D. Origin and development of muscle cramps. Exerc Sport Sci Rev. 2013;41(1):3-10.

25. Reboredo MM, Faria RS, Portes LH, Mol CG, Pinheiro BV, Paula RB. Exercício aeróbico durante a hemodiálise: relato de cinco anos de experiência. Fisioter Mov. 2011;24(2):239-46. 
26. Soares KTA, Viesser MV, Rzniski TAB, Brum EP. Eficácia de um protocolo de exercícios físicos em pacientes com insuficiência renal crônica, durante o tratamento de hemodiálise, avaliada pelo SF-36. Fisioter Mov. 2011;24(1):133-40.

27. Bradshaw W. Intradialytic hypotension: a literature review. Renal Society of Australasia Journal. 2014;10(1):22-9.

28. Leal FJ, Couto RC, Silva TP, Tenório VO. Vascular physiotherapy in treatment of chronic venous disease. J Vasc Bras. 2015;14(3):224-30.

29. Faria RS, Silva VSA, Reboredo MM, Fernandes NMS, Bastos MG, Cabral LF. Avaliação da função respiratória, capacidade física e qualidade de vida de pacientes com doença renal crônica pré-dialítica. J Bras Nefrol. 2008;30(4):264-71.
30. Posser SR, Cecagno-Zanini SC, Piovesan F, Leguisamo CP. Functional capacity, pulmonary and respiratory muscle strength in individuals undergoing hemodialysis. Fisioter Mov. 2016;29(2):343-50.

31. Pellizzaro CO, Thomé FS, Veronese FV. Effect of peripheral and respiratory muscle training on the functional. Ren Fail. 2013;35(2):189-97.

32. Rocha E, Magalhães SM, Lima VP. Repercussão de um protocolo fisioterapêutico intradialítico na funcionalidade pulmonar, força de preensão manual e qualidade de vida de pacientes renais crônicos. J Bras Nefrol. 2010;32(4):359-71.

Received in 02/01/2018

Recebido em 01/02/2018

Approved in 02/26/2018

Aprovado em 26/02/2018 